\title{
THE ROLE OF PNEUMATOLOGY IN THE ETHICS OF STANLEY HAUERWAS
}

Nico Koopman

University of Stellenbosch

\begin{abstract}
This paper explores the role of pneumatology in the ethics of Stanley Hauerwas. It demonstrates that the theme of pneumatology is underdeveloped in his ethical project. The implications of this inadequate pneumatology are spelled out. Simultaneously it is indicated how Hauerwas' ethics and the significance thereof can be served by a greater emphasis on pneumatology. This paper is structured as follows: The main themes of and developments in Hauerwas' thinking is briefly outlined (1). Thereafter the role of pneumatology in his thinking, or rather perhaps lack thereof, is specifically investigated (2). In a next part the implications of an inadequate pneumatology for his ethics - specifically in terms of the relationship between the anthropological and pneumatologial sides of (a) moral formation and (b) the sectarian character of his ethics are outlined. The paper concludes with suggestions for the improvement of his ethical project,.
\end{abstract}

\section{Agency, narrative and community}

Broad consensus exists amongst investigators of Hauerwas' ethics that his ethics can be described in terms of three major themes or categories, namely character or moral agency, narrative and community. ${ }^{1}$ There is also agreement on a pattern of development in his thinking. In his early phase the focus is on moral agency. Themes such as beliefs, vision, virtue and virtues as well as character are emphasized in this phase. In his second phase the focus is on narrative. The emphasis on narrative enables Hauerwas to describe the themes of his earlier phase more concretely in biblical and theological terms and less in abstract, phenomenological and philosophical terms. The third phase in his development is the shift to community, specifically to the Christian church. The dominance of the church in his thinking caused several theologians to describe his ethics as ecclesial ethics. ${ }^{2}$ It should be noted that all these themes appear throughout in Hauerwas' work, but that specific themes are emphasized stronger in particular stages in his thinking.

Hauerwas develops these themes in opposition to the liberal or modern approach to ethics, which is the dominant approach to ethics since the Enlightenment. Against this

1. The Swedish theologian, Arne Rasmusson in his dissertation on the ethics of Hauerwas and Moltmann, entitled The Church as polis. From Political Theology to Theological Politics as exemplified by Jürgen Moltmann and Stanley Hauerwas (1994:177-178), as well as the South African theologian, Robert Vosloo in his dissertation on the ethics of Hauerwas, entitled Verhaal en moraal: 'n Kritiese ondersoek na die Narratiewe Etiek van Stanley Hauerwas (1994:48), divide the work of Hauerwas in the three subsequent phases of character, narrative and community. In my doctoral dissertation on the ethics of Hauerwas and Harry Kuitert, entitled Dade of deugde? Implikasies vir Suid-Afrikaanse kerke van 'n modern-postmoderne debat oor die moraliteit, I described his first phase as that of moral agency, rather than character, because the term, moral agent, is more inclusive and include concepts like beliefs, dispositions, virtue and character.

2. The German theologian, Reinhold Hütter, in an article entitled The ecclesial ethics of Stanley Hauerwas (1991), as well as the Namibian theologian, De Wet Strauss, in his dissertation, entitled ' $n$ Kerk om in te glo. Die prioriteit van die kerk in die Christelike geloof (1997), describe Hauerwas's ethics as ecclesial, because of the dominant role of the notion of community, specifically he Christian church, in Hauerwas's thinking. 
background the postliberal ${ }^{3}$ position of Hauerwas can be outlined as follows according to an article, entitled From System to Story: An Alternative Pattern for Rationality in Ethics, which he wrote with David Burrell:

It is not possible for moral agents to make moral decisions from a position of disinterest and objectivity with regard to their needs, interests, passions, past and present (1989a:171-173). Character, which is formed by narrative, determines one's moral decisions (1989a:166-167). The nature of human beings is not grounded in the idea of a presumed universal rationality, but in the fact that human beings need a narrative, which gives coherence to their lives (1989a:176-177). Morality is not a-historic and narrative free, but linked to the story of the triune God Who acts in history (1989a:168-172). Isolation from community does not bring freedom, but exactly the commitment to the community which is formed by the stories of Israel and Jesus Christ, brings that freedom which implies that we are committed to something of real value (Hauerwas 1983:8-16).

In later works Hauerwas elaborates extensively on these themes. His influence has grown immensely and his works are read increasingly in various parts of the world. In the circles of the World Council of Churches growing attention is given to Hauerwas' agent-, narrative- and community-dependent ethics. His approach to ethics is also increasingly appreciated by South African scholars. ${ }^{4}$ The next section of this paper, however, shows that Hauerwas' work is not without weaknesses.

\section{The absence of pneumatology in Hauerwas' ethics?}

In 1998 Hauerwas wrote about the challenge that Nigel Biggar posed to him in 1986 about the absence of the doctrine of God in his thinking until that time:

Even if I have shown the difference that Christian convictions may or should make for how our lives are shaped, such a project does not in itself entail that the god in view be the God we worship as Father, Son and Holy Spirit. That failure, however, may not be peculiar to me alone but may be the fate of theology in modernity (Hauerwas 1998: $37-38)^{5}$

Despite this acknowledgement there is not evidence of a significant shift to trinitarian and pneumatological thinking in his later writings. As a theologian who is greatly influenced by Karl Barth, his ethical approach is Christocentric and ecclesial. However, some of the criticism of Christomonism that is leveled- unfairly I think as I will show later - against Barth, does apply to a certain extent to Hauerwas. This is due to a weakness in his pneumatology.

This position is echoed by important critics of his work. Rasmusson is of opinion that pneumatology is only implied in the ecclesiology of Hauerwas. He reckons, however, that Hauerwas's theology might be strengthened if he develops it in a more explicit

3. Hauerwas's position is being described as postliberal because his ethical thinking corresponds with the socalled Yale school of theologians. These theologians, according to Jeffrey Stout in the lexicon of his book Ethics after Babel, correspond in their efforts to free theology from all forms of modernism.

4 Various South African scholars focused in their doctoral dissertations, amongst others, on the work of Hauerwas, namely Neville Richardson, Robert Vosloo, Andrew Phillips, De Wet Strauss and myself. Moreover, Systematic theologians such as Dirkie Smit and Ettienne De Villiers and an increasing number of Practical theologians such as Coenie Burger give serious attention to the work of Hauerwas.

5. Elsewhere Hauerwas also admits that his theology has an inadequate trinitarian and by implication pneumatological basis: I believe my work has at times been insufficiently trinitarian (1994:210). 
pneumatological framework (1994:179). Hütter formulates the inadequate pneumatology of Hauerwas even stronger: There is especially the very weak and almost absent pneumatology in Hauerwas' ecclesiology (1991:240).

It is quite clear that Hauerwas' does not attend adequately to the theme of pneumatology in his ethics. The consequences of this deficiency in his thinking, firstly, for his understanding of the relationship between the pneumatological and anthropological dimension of the moral life and, secondly, for the social significance of his ethics are consequently investigated. These two aspects are highlighted here because, by dealing with them, the broader scope of Hauerwas' ethics comes into focus. Simultaneously these two themes represent the areas in which he receives much criticism. An adequate response to this criticism might enhance the significance of Hauerwas' ethical project.

\section{Pneumatology and moral formation}

In this section we investigate the implications of Hauerwas' insufficient pneumatology for his appreciated emphasis on the virtuous life. Hauerwas' emphasis on notions such as virtue and character perhaps makes him the most prominent Protestant theologian who encourages churches to focus on the so-called anthropological side of the process of sanctification and eventually of moral formation. His position is, however, not without strong criticism from fellow Protestants. In this regard the critique of the North American Methodist ${ }^{6}$ theologian, Don Zinger, on Hauerwas' view of the relationship between grace and virtue-formation is helpful.

Zinger's criticism entails that Hauerwas does not give sufficient attention to the role of the Spirit and the grace of God in justification. He is of opinion that Hauerwas does not escape Luther's strong criticism of the virtue ethics of his day, namely that it is a wedge for works righteousness which squeezes righteousness out of the spiritual resources of human beings (1989:12).

According to Zinger this inadequate presence of the divine initiative in Hauerwas' virtue ethics has the implication that he does not ground sanctification in justification but that sanctification and justification are synonymous, that the role of justification by grace is underestimated in his soteriology, that the formative role of the church is overestimated and that soteriology merely implies exemplarism. If the Spirit can receive an appropriate place in Hauerwas's ethics, it might respond more adequately to this challenge that Zinger formulates:

Our time needs an account of the Christian life that portrays it as spontaneous and yet examined, as Spirit given and yet given to virtues that have full human grounding and do not seem to come out of the blue of intuition. Christian ethical theory in our day needs the stimulus of a virtue-character position, if such an account can avoid moralism and legalism, if indeed parish life can be a focus of moral education, rooted in grace (1989:13).

Hauerwas might be in a better position to respond to the above and related criticisms if he can give a more appropriate role to the Spirit in the process of sanctification.

As indicated earlier, Hauerwas' ethics is largely influenced by Barth. However, his ethics might be enriched if he could follow Barth also with regard to Barth's view on the role of the Spirit in ethics. In a $1929^{7}$ lecture, entitled The Holy Spirit and the Christian

6. The view of a Methodist theologian is helpful since Hauerwas himself is a member of the Methodist Church.

7. In this essay I use the 1993 publication of this lecture with a foreword by Robin W Lovin. 
Life. The Theological Basis of Ethics, Barth portrays, as the title suggests, the role of the Spirit in ethics. He specifically emphasises the role of the Spirit with regard to justification and sanctification.

Barth appeals to Augustine, Luther and Calvin in formulating his stance on the role of the Holy Spirit with regard to justification and sanctification.

He is in agreement with Augustine's view that it is the Spirit Who opens our eyes to the grace of God and Who gives us faith.

In his (Augustine's - NNK) fight against Pelagians and semi-Pelagians he attributed to the free, unmerited operation of the Holy Spirit the willing and production, the receiving and the preservation of grace, and the establishment and the stability of the Christian life. He taught justification by faith and undoubtedly designated faith as a gift of God (1993: 21 - emphasis NNK).

Barth, however, is of opinion that Augustine and the Catholic tradition disturbs the nature of faith and grace, and consequently also of justification and sanctification, by establishing too close a connection between faith and the works of love so that love is perceived as the standard, criterion and decisive content of faith (1993:21-25,33). At this point Barth's critique of Augustine, which is based in Augustine's description of the role of the Spirit echoes Zinger's above-mentioned critique of Hauerwas, which is due to Hauerwas' inadequate pneumatology:

But unfortunately he likewise undoubtedly sought justification in the immediately perceptible actuality of the new obedience. He not only made justification coincide with sanctification but made justification pass into sanctification, interpreting grace as 'the inspiration of goodwill and of works' and faith as the impartation of man's own ability to will and to perform what was commanded by the law. (1993:21)

Barth does not doubt that Augustine and the later official Catholicism gives room to the Spirit. However, he is against the way they define the role of the Spirit, namely that the Spirit imparts a divine quality to the human soul and that He uplifts the human beings to the position of non-sinners. This status of human beings leads to a synergism, which involves that God's grace, and the religious fervour, moral earnestness and creative activity of human beings cooperate in the salvation of human beings (1993:22-23).

Barth judges more positively on the Reformers' view on the relationship between justification and sanctification. He identifies with the role that the Reformers attribute to the Spirit. He supports Luther's view that it is the task of the Spirit to convince us that our reliance on good works is unbelief, the enemy of grace and sin against God (1993:28). Barth refers with affirmation to Luther's view that it is the Holy Spirit Who, as Comforter, makes us comfortable with God's grace and afraid of works (1993:27,36-37). Barth agrees with Luther's view that the Holy Spirit helps us to believe, to confide in and trust God's word which tells us that our gravest sins have been taken away by the passion and death of Christ and of the unmerited imputation of his righteousness to us (1993:29) He accentuates Luther's position that the Holy Spirit protects us against the temptation that our status as simul peccator et justus is regarded as a judgment upon us, and not as a pardon (1993:31). It is clear that Barth teaches that the Holy Spirit fulfils an indispensable role in the process of justification by grace and faith.

Barth criticises Augustine and the Catholic tradition for mixing justification and sanctification and consequently disturbing the nature of grace and faith. Sanctification, according to him and the Reformers, should be distinguished from justification. We are not justified because of our sanctification, neither are we justified without it. Sanctification cannot tell us what grace is, but it can tell us how grace is active on our behalf (1993:33). 
Barth agrees with Luther and Calvin that we are passive in this process of sanctification and that it is the Holy Spirit Who makes our works forgiven, without guilt and good (1993:3637). In the Kirchliche Dogmatik he pertinently identifies with Calvin's distinction between justification and sanctification and with his description thereof as a duplex gratia. In this work he is of opinion that Luther does not distinguish sufficiently between justification and sanctification (KD IV/2 1955:565-578). Barth stresses the redemptive role of the Holy Spirit also in other parts of his Kirchliche Dogmatik. He, for instance describes the Holy Spirit as the resurrection power by which Christ calls sinners to believe in Him. Faith according to Barth is not possible without the Holy Spirit (KD IV/1 1960:826).

From the outline above it becomes clear that Barth develops a role for pneumatology in soteriology, which is in broad correspondence with the Reformers and to an extent with Augustine. The active role of the Spirit in Barth's soteriology indeed helps him to avoid dangers that Hauerwas cannot avoid. Although Barth's pneumatology is not without flaws ${ }^{8}$ - and Hauerwas will do well to avoid them, an adherence to Barth not only with regard to his Christocentrism but also with regard to his pneumatology can help Hauerwas to distinguish more clearly between justification and sanctification, to give appropriate emphasis to the grace of God, to avoid a wrong portrayal of the nature of faith and eventually to answer more adequately to the accusations of signs of works righteousness in his character ethics.

\section{Pneumatology and social ethics}

Hauerwas is famous for the view that the church does not have a social ethic but that it is a social ethic. With this description of the church Hauerwas means that the church does not have to sit down and formulate a social ethic. If the church lives true to the narratives that called her into existence and that form and transform her, she portrays the reality of the kingdom which is what the world really is and should be, a reality where the virtues flourish and where there are no signs of evils such as injustice, racism and classism. The church is not involved in social ethics to make society, especially the democratic society works, that is for Constantinian reasons, but because she is faithful to her narratives (1983:99; 1989). Despite this position, Hauerwas is accused of sectarianism. The sectarianism, which is envisaged here, is not doctrinal sectarianism, but sociological sectarianism. Various scholars level this accusation against him.

The feminist theologian Gloria Albrecht is of opinion that Hauerwas is not open to the oppressive nature of the Christian narrative, despite his emphasis on the historical and particular nature of this narrative. She reckons that despite his focus on the historical and particular, he ironically in the end constructs a view of humanity and of sin, which does not take account of historical, economic, political and gender context (1992:108-112):

Thus, while endorsing the social context of language, he presents a Christian narrative in which words, such as 'life', 'freedom', 'family', 'woman', 'violence', 'power', 'suffering' and 'sin', are assumed to be univocal for all Christians regardless of the

8. The Catholic theologian, Philip Rosato, reckons that Barth's Christological pneumatology emphasises the filioque to such an extent that the being of the Holy Spirit is obscured by Christ (The Spirit as Lord. The Pneumatology of Karl Barth 1981:182-189). Berkouwer is of the opinion that, although Barth's pneumatology succeeds in safeguarding the empty and unmerited character of faith over against Pelagianism, semiPelagianism and Remonstrantism, it does not adequately stay true to the biblical view that, although faith is empty and focused on the grace of God, it is essential for redemption. Barth underestimates the redemptive value of the empty faith (Berkouwer 1954:263f.). This criticism coincides with Rosato's view that Barth's pneumatology causes the being of the human person to be obscured by Christ (1981:186). 
temporal and spatial specificity of their location and regardless of their race, class, sex or sexual orientation (1992:114).

Albrecht states that Hauerwas' appeal for the ideal marriage, which is a sign of hope and of God's providence in a hopeless world, actually strengthens the oppression of women since he does not address the injustice towards women directly (1992:112-113).

James Gustafson claims that Hauerwas does not succeed in resisting what he calls the sectarian temptation. Hauerwas' ethics gives Christians clarity about their distinct identity and behaviour. Unfortunately, according to Gustafson, the negative consequences of this achievement are that Christianity is isolated from taking the wider world of science and culture seriously. Moreover, Christianity becomes unintelligible and does not participate in universities, politics and broader social life (1985:84-94).

Neville Richardson is of the opinion that the argument in favour of the uniqueness of the church is emphasised to such an extent by Hauerwas that it eventually leads to an inadequate response in his ethical project to social injustice. Thereby the potential of his ethics for a continent such as Africa with its various forms of social injustices is limited (1997:383).

Hauerwas can defend himself better against accusations such as these if he strengthens his pneumatology. In this regard he might also learn from Barth. Although Barth's description of the role of the Holy Spirit in the social ethical task of the church is not without criticism, ${ }^{9}$ the point is that he makes more of the Spirit than Hauerwas and that his ethics consequently does not have the sectarian character like that of Hauerwas.

Strauss is of the opinion that the motivation for Barth's political involvement is to be found in the close relatedness of his ecclesiology, Christology and pneumatology. He refers to Barth's view that the church is the act of the Spirit of Christ and therefore the firstborn of the total, universal redemption of the world (1997:25).

This view of Strauss is supported by explicit remarks of Barth on the role of the Holy Spirit in the social ethical task of the church. He, for instance, states that the Holy Spirit draws the church out of passivity and detachment and into involvement and solidarity with the world. The Holy Spirit enables us to take up our God-given responsibility for the world (KD IV/3.2, 1959:888f.). He even states that in the action of the Holy Spirit divine and human action forms a parallel history (KD IV/3.2, 1959:870f.).

The crucial role of the Holy Spirit in the social ethical task of the church was increasingly emphasized by various strands of theology in the twentieth century. Willie Jonker refers to the indispensable social and political roles that the Spirit fulfils in the theologies of liberation and revolution and also in the political theologies (1983:256-260).

The aforementioned views on the relationship between pneumatology and social ethics affirm that as we are dependent on the Spirit for sanctification and the consequent process of moral formation, we are dependent on the Spirit to avoid sectarianism and a-historicism and to fulfil our social ethical responsibility in the world. An appropriate emphasis by Hauerwas on the Spirit can give him the theological tools to avoid the danger of sectarianism in his ethical approach and to respond more adequately to criticisms in this regard. An adequate pneumatology might help him to show the potential of the Spirit and, through the Spirit, of the church for causing moral transformation not only within the church but in surprising ways also outside the church. A stronger pneumatology might help

9. Richard Hays, for instance, reckons that Barth's high level of political involvement is not due to the motive to bring about political change, but to proclaim the kingship of Christ over all earthly authorities. Moreover, this high level of political involvement, according to Hays, is not really compatible with Barth's theological methodology (1996:239). 
Hauerwas to develop an ethic that offers a way to churches to be simultaneously true to their identity and to be involved in social and public matters. In fact, such a pneumatology might help to show how true Hauerwas' view on ethics really is, namely that the social ethic of the church is to be the church.

It can also be mentioned that a more adequate pneumatology will also ensure that Hauerwas's ethics has a trinitarian basis with all the advantages that this brings. ${ }^{10}$

This paper concludes that the ethics of Hauerwas deserves the attention of South African churches. By developing a more adequate pneumatology the potential of his ethical approach for the South African and other contexts might be increased significantly.

10. In my doctoral dissertation I refer, with an appeal to amongst others, Robert Vosloo and the Dutch ethicist Hans Reinders, to the ways in which a trinitarian approach can enrich the ethics of Hauerwas. Vosloo states that a trinitarian emphasis would more sufficiently open the way for other shapes of discipleship than the exclusive accent on Christ. It would increase the potential of his ethics for a pluralistic society (2001:367). According to Reinders a trinitarian emphasis in ethics will help us to get rid of the modernistic view of the autonomous, independent human being and open our eyes for an image of human beings which reflect dependence and mutuality as in the being of God. In this context proper recognition is given to the so-called weaker members of society like the mentally disabled (2001:367-369). 


\section{BIBLIOGRAPHY}

Albrecht, GH 1992. Myself and Other Characters: A Feminist Liberationist Critique of Stanley Hauerwas's Ethics of Christian Character. The Annual of the Society of Christian Ethics, 97-114.

Barth, K 1963. The Holy Spirit and the Christian Life. The theological basis of ethics. Translated by R Birch Hoyle. Louisville: John Knox.

Biggar, N 1993. The hastening that waits. Karl Barth's ethics. Oxford:Clarendon Press.

Comblin, J 1989. The Holy Spirit and Liberation. Translated from the Portuguese by Paul Burns. New York: Orbis Books.

Gustafson, JM 1985. The Sectarian Temptation: Reflections on Theology, the Church and the University. Catholic Theological Society 40, 83-94.

Hauerwas, S 1983. The Peaceable Kingdom: A Primer in Christian Ethics. Notre Dame: University of Notre Dame Press.

Hauerwas, S and Burrell, D 1989a. From System to Story: An Alternative Pattern for Rationality in ethics. In: Hauerwas, S \& Jones, LG: Why Narrative? Readings in Narrative Theology. Grand Rapids: Eerdmans.

Hauerwas, S and Willimon, W 1989b. Resident Aliens: Life in the Christian Colony. Nashville: Abingdon Press.

Hauerwas, S 1994. Dispatches From the Front: Theological Engagements With the Secular. Durham: Duke University Press.

Hauerwas, S 1997. In Good Company. The Church as Polis. ${ }^{2}$ Notre Dame: University of Notre Dame Press.

Hauerwas, S 1998. Sanctify them in the truth. Holiness exemplified. Nashville: Abingdon Press.

Hays, RB 1996. The moral vision of the New Testament. A contemporary introduction to New Testament Ethics. San Francisco: Harper.

Hütter, R 1991. The ecclesial ethics of Stanley Hauerwas. Dialog 30, 231-241.

Jonker,WD 1983. Die Gees van Christus. Pretoria: NG Kerkboekhandel.

Koopman, NN 2001 . Dade of Deugde? Implikasies vir Suid-Afrikaanse kerke van 'n modernpostmoderne debat oor die moraliteit. Unpublished doctoral thesis. University of the Western Cape.

Moltmann, J 1993. The Spirit of Life: A universal affirmation. Minneapolis: Fortress Press.

Rasmusson, A 1994. The church as polis. From Political Theology to Theological Politics as exemplified by Jürgen Moltmann and Stanley Hauerwas. Studia Theologica Lundensia 49. Lund: Lund University Press.

Richardson, N 1997. Community in Christian Ethics and African Culture. Scriptura 62,.373-385.

Rosato, PJ 1981. The Spirit as Lord. The pneumatology of Karl Barth. Edinburgh: T \& T Clark.

Stout, J 1988. Ethics after Babel: the language of Morals and their discontents. Boston: Beacon Press.

Strauss, JJD 1997. 'n Kerk om in te glo. Die prioriteit van die kerk in die Christelike geloof. Unpublished doctoral thesis. University of the Western Cape.

Van de Beek, A 1987. De adem van God. De Heilige Geest in kerk en kosmos. Nijkerk: Callenbach.

Vosloo, RR 1994. Verhaal en moraal: 'n kritiese ondersoek na die narratiewe etiek van Stanley Hauerwas. Unpublished doctoral thesis. University of the Western Cape.

Willis, RE 1971. The ethics of Karl Barth. Leiden: Brill.

Zinger, DH 1989. Are Grace and Virtue Compatible? Lutheran Forum 23/1, 12-13. 